\begin{abstract}
Arun Kumar Jha ${ }^{1 \star}$, Sanjim Chadha ${ }^{1}$, Beena Uppal ${ }^{1}$, Preena Bhalla ${ }^{1}$, Jugal Kishore $^{2}$ and Richa Dewan ${ }^{3}$

${ }^{1}$ Department of Microbiology, Maulana Azad Medical College, New Delhi, India

${ }^{2}$ Department of Community Medicine, Maulana Azad Medical College, New Delhi, India

${ }^{3}$ Department of Medicine, Maulana Azad Medical College \& Lok Nayak Hospital, New Delhi, India
\end{abstract}

Dates: Received: April 16, 2014; Accepted: June 16, 2014; Published: June 18, 2014

*Corresponding author: Dr. Arun Kumar Jha, M.D., Senior Resident, Department of Microbiology, Maulana Azad Medical College, New Delhi-110002, India, Tel: 00919868489408; 0091-11-22796492; Fax: 91-11-23235574; Email: dr_jhauc2k@yahoo.co.in

www.peertechz.com

ISSN: 2455-3786

Keywords: Socio-demographic profile; HIVIAIDS; Immunological profile; CD4+ T lymphocyte count (CD4+ count); WHO staging of AIDS

\section{Research Article \\ Socio-demographic and immunological profile of HIV patients attending ART clinic in a tertiary care hospital in North India}

\section{Abstract}

Background: The epidemiology of HIV should be understood especially with regard to various socio-demographic factors because the most effective approaches for its prevention and control are awareness and life style changes.

Aim: This study was undertaken to determine the socio-demographic characteristics and immunological profile of HIV seropositive patients attending the antiretroviral therapy (ART) clinic of Lok Nayak hospital in New Delhi, India.

Methods: Two hundred and fifty two, HIV seropositive subjects were enrolled in the study irrespective of their ART status. Subjects were staged as per the World Health Organization (WHO) staging system and the socio-demographic data and clinical signs and symptoms were recorded for all subjects on a predesigned performa. CD4+ T lymphocyte count was determined by the Fluorescent Activated Cell Sorting (FACSCount ${ }^{\mathrm{TM}}$ ) system

Results: Mean age of study subjects was 33.6 years \pm 8.3 years, $66.3 \%$ were males, $73.4 \%$ were married, $27.7 \%$ were illiterate. $32.9 \%$ of subjects were employed in unskilled and semiskilled occupations. Majority of patients belonged to upper lower social class as per the modified Kuppuswamy's scale. $72.2 \%$ had acquired infection through the heterosexual route. $66.3 \%$ of the cases were in WHO clinical stage I \& II of illness at the time of registration. The median CD4+ T lymphocyte count for all patients was 279 Cells/ $\mu \mathrm{l}$.

Conclusions: Literacy status, occupation, socio-economic status and place of residence were the socio-demographic determinants found to be associated with HIV positivity. The commonest mode of acquiring infection was heterosexual contact.

\section{Abbreviations}

AIDS: Acquired Immune Deficiency Syndrome; ART: Antiretroviral Therapy; ELISA: Enzyme Linked Immunosorbent Assay; ICTC: Integrated Counseling and Testing Center; IQR: Interquartile range; NACO: National AIDS Control Organization; WHO: World Health Organization

\section{Background}

Since the summer of 1981, when Acquired Immune Deficiency Syndrome (AIDS) was first discovered, it has taken the world by surprise. It has now become a deadly pandemic. Humankind has not been able to avert this serious disease as no effective immunization, drugs or anti-toxins have been developed to prevent this disease.

The AIDS epidemic targets people in their most productive years that are strong young adults, which lead to disastrous economic, political and socio-demographic consequences. It is $100 \%$ fatal without life-long treatment with antiretroviral drugs. It is sexually transmitted, and such infections are known for being difficult to control, even when treatment is available $[1,2]$.
Science has responded to the challenge of AIDS by rapidly identifying etiology, describing pathogenesis and transmission routes, and developing diagnostic tests and treatment but this has not stopped the global spread. According to UNAIDS estimates, there were 33.3 million people living with HIV at the end of 2009, compared with 26.2 million in 1999. Although the annual number of new HIV infections (2.6 million in 2009 to 3.1 million in 1999) has been steadily declining since the late 1990s, this decrease is offset by the reduction in AIDS-related deaths (2.1 million in 2004 to an estimated 1.8 million in 2009) due to the significant scale up of antiretroviral therapy over the past few years [3].

India being the world's most populated country has also faced the brunt of this epidemic. India is a nation of contrasts. The economy is modernizing, but the culture is largely traditional. There are multiple religions and languages. There is ignorance about the disease, fear of discrimination and consequent denial for testing and treatment. Violence against women is common and this makes women more vulnerable. More than $70 \%$ of its people reside in rural areas. The World Bank has categorized India as a low-income country. 
Prevention of HIV transmission is hampered due to all these factors and the task of controlling HIV/AIDS in India is gigantic [4-6].

Based on HIV Sentinel Surveillance 2008-09, it is estimated that India has an adult prevalence of 0.31 percent with 23.9 lacs people infected with HIV. The number of new annual HIV infections has declined and is estimated to be approximately 1.2 lacs new HIV infections in 2009, against 2.7 lacs in 2000. Of the 1.2 lacs estimated new infections in 2009, the six high prevalence states (Manipur, Andhra Pradesh, Mizoram, Nagaland, Karnataka and Maharashtra) account for 39 percent of the cases [7].

Our study reports the socio-demographic characteristics of HIV/ AIDS patients from one of the largest tertiary care hospital in New Delhi, India. Our center caters to patients not only from Delhi but also from adjoining states of North India like Haryana, Uttar Pradesh, Himachal Pradesh, Madhya Pradesh and Punjab.

\section{Materials and Methods}

This cross-sectional descriptive study was carried out in the Department of Microbiology, Maulana Azad Medical College, New Delhi, India from February 2008 to January 2011. After approval from institution's ethical committee two hundred and fifty two (167 males and 85 females) adult ( $>18$ years) HIV seropositive subjects were enrolled for this study from the Antiretroviral Therapy (ART) Clinic of Lok Nayak Hospital, New Delhi irrespective of their ART status. Subjects were registered with the ART clinic, following which a detailed clinical history was recorded and a complete physical examination was conducted. Subjects were staged as per the World Health Organization's (WHO) staging system. An informed consent was obtained and proper counseling was done. Socio-demographic data and clinical signs and symptoms were recorded for all subjects on a predesigned performa, at the time of recruitment.

HIV status of all subjects was confirmed by performing two to three Enzyme Linked Immunosorbent Assay (ELISA) / rapid tests depending on the presence or absence of symptoms suggestive of AIDS as per National AIDS Control Organization (NACO) guidelines, at the Integrated Counseling and Testing Center (ICTC) for AIDS, Department of Microbiology, Maulana Azad Medical College, New Delhi, India. Blood samples were collected from all subjects and a CD4+ T lymphocyte count was performed to assess their immunological status by the Fluorescent Activated Cell Sorting (FACSCount ${ }^{\mathrm{TM}}$ ) system (Becton, Dickinson and company).

\section{Results}

The socio-demographic characteristics of the study subjects were shown in Table 1. The male to female ratio of the study subjects recruited was 1.96: 1 . The mean age of study subjects was 33.6 years \pm 8.3 years (range 18-63 years), with the predominant age group being 26-35 years which is the sexually active age group. $79.6 \%$ of the males were married while only $61.1 \%$ of females were married. $44.9 \%$ of males had HIV positive sexual partners while $82.3 \%$ females had HIV positive sexual partners.

A total $26.9 \%$ male and $29.4 \%$ female were illiterate. Only $28.1 \%$ of patients had received education above Intermediate level. Majority
Table 1: Socio-demographic determinants of study subjects $(n=252)$.

\begin{tabular}{|c|c|c|c|}
\hline Characteristics & & Number & Percentage \\
\hline Gender & $\begin{array}{l}\text { Males } \\
\text { Females }\end{array}$ & $\begin{array}{r}167 \\
85\end{array}$ & $\begin{array}{l}66.3 \\
33.7\end{array}$ \\
\hline Age & $\begin{array}{l}18-25 \\
26-35 \\
36-45 \\
>45\end{array}$ & $\begin{array}{r}61 \\
109 \\
71 \\
11\end{array}$ & $\begin{array}{r}24.2 \\
43.3 \\
28.2 \\
4.4\end{array}$ \\
\hline Residential Status & $\begin{array}{l}\text { Urban } \\
\text { Rural }\end{array}$ & $\begin{array}{r}175 \\
77\end{array}$ & $\begin{array}{l}69.4 \\
30.6\end{array}$ \\
\hline $\begin{array}{l}\text { State-wise } \\
\text { distribution }\end{array}$ & $\begin{array}{l}\text { Delhi } \\
\text { Uttar Pradesh } \\
\text { Haryana } \\
\text { Himachal Pradesh } \\
\text { Madhya Pradesh }\end{array}$ & $\begin{array}{r}168 \\
76 \\
2 \\
5 \\
1\end{array}$ & $\begin{array}{r}66.6 \\
30.2 \\
0.8 \\
2 \\
0.4\end{array}$ \\
\hline Marital Status & $\begin{array}{l}\text { Married } \\
\text { Single } \\
\text { Widowed }\end{array}$ & $\begin{array}{r}185 \\
32 \\
35\end{array}$ & $\begin{array}{l}73.4 \\
12.7 \\
13.8\end{array}$ \\
\hline $\begin{array}{l}\text { HIV status of the } \\
\text { partner }\end{array}$ & $\begin{array}{l}\text { Positive } \\
\text { Negative } \\
\text { Not tested }\end{array}$ & $\begin{array}{r}145 \\
49 \\
58\end{array}$ & $\begin{array}{r}57.5 \\
19.4 \\
23 \\
\end{array}$ \\
\hline Educational Status & $\begin{array}{l}\text { Illiterate } \\
\text { Primary school } \\
\text { Middle school completion } \\
\text { High school certificate } \\
\text { Intermediate } \\
\text { Graduate degree } \\
\text { Post Graduate degree }\end{array}$ & $\begin{array}{r}70 \\
40 \\
36 \\
35 \\
46 \\
23 \\
2\end{array}$ & $\begin{array}{r}27.7 \\
15.9 \\
14.3 \\
13.9 \\
18.3 \\
9 \\
0.8\end{array}$ \\
\hline $\begin{array}{l}\text { Occupational } \\
\text { Status }\end{array}$ & $\begin{array}{l}\text { Unemployed } \\
\text { Unskilled worker } \\
\text { Semiskilled worker } \\
\text { Skilled worker } \\
\text { Clerical, Shop owner, Farm owner } \\
\text { Semi-professional } \\
\text { Professional }\end{array}$ & $\begin{array}{r}86 \\
66 \\
17 \\
45 \\
30 \\
8 \\
0\end{array}$ & $\begin{array}{r}34.1 \\
26.2 \\
6.7 \\
17.9 \\
11.9 \\
3.2 \\
0\end{array}$ \\
\hline Per capita income & $\begin{array}{l}<\text { Rs } 979 \\
\text { Rs } 980-\text { Rs } 2935 \\
\text { Rs 2936-Rs } 4893 \\
\text { Rs 4894- Rs } 7322 \\
\text { Rs } 7323-\text { Rs } 9787 \\
\text { Rs 9788- Rs } 19574 \\
\text { Above 19575 }\end{array}$ & $\begin{array}{r}118 \\
104 \\
17 \\
5 \\
3 \\
3 \\
2\end{array}$ & $\begin{array}{r}46.8 \\
41.3 \\
6.7 \\
2 \\
1.2 \\
1.2 \\
0.8\end{array}$ \\
\hline $\begin{array}{l}\text { Socio-economic } \\
\text { Class }\end{array}$ & $\begin{array}{l}\text { Lower } \\
\text { Upper Lower } \\
\text { Low Middle } \\
\text { Upper Middle } \\
\text { Upper }\end{array}$ & $\begin{array}{r}32 \\
176 \\
35 \\
8 \\
1\end{array}$ & $\begin{array}{r}12.7 \\
69.8 \\
13.9 \\
3.2 \\
0.4\end{array}$ \\
\hline $\begin{array}{l}\text { Mode of } \\
\text { Transmission }\end{array}$ & $\begin{array}{l}\text { Heterosexual contact } \\
\text { I/V drug abuse } \\
\text { Blood Transfusion } \\
\text { Needle Stick Injury } \\
\text { MSM } \\
\text { Not known }\end{array}$ & $\begin{array}{r}182 \\
12 \\
9 \\
7 \\
3 \\
39\end{array}$ & $\begin{array}{r}72.2 \\
4.8 \\
3.6 \\
2.8 \\
1.2 \\
15.5\end{array}$ \\
\hline
\end{tabular}

(65.9\%) of subjects were employed. $74 \%$ females were unemployed while only $13.5 \%$ males were unemployed. $88.1 \%$ of study subjects had a per capita income of less than Rs 2935/- per month. Median per capita income for the study population was Rs 1000/- per month. Socio-economic status of study subjects was calculated by using modified Kuppuswamy's scale based on education, occupation and per capita income of head of the family [8]. Majority of patients belonged to upper lower social class. As expected, the commonest mode of acquiring the infection was through heterosexual contact. 
Route of transmission could not be identified in $15.5 \%$ of study subjects.

The clinical status of study subjects were shown in Table 2 . Maximum number (49.6\%) of study subjects were in Stage I of clinical disease while just 6 cases were in the WHO clinical stage IV. $85.3 \%$ of our cases were physically active and were able to perform jobs outside the house and $2 \%$ cases were bedridden.

Table 3 shows the CD4+ T lymphocyte counts of our study subjects with regard to their clinical stage of disease. The median CD4+ T lymphocyte count for all patients was 279 Cells/ $\mu l$ with an inter-quartile range (IQR) of 154 - 482.

\section{Discussion}

The present study shows the mean age of study subjects as $33.6 \pm$ 8.3 years (range 17-63 years); with the predominant age group being 26-35 years which is the sexually active age group but unfortunately is also the economically most productive age group. This was slightly lower than what was reported from a study in Ahmedabad, India in 2010 wherein the mean age of study subjects was $38.7 \pm 10.3$ years with the predominant age group being 15-44 years [9]. Our study showed prevalence of more males $(66.3 \%)$ than females with male:female ratio 1.96:1. Predominance of male cases may be due to their migration to the metropolitan cities (Delhi being one such type) in search of work. Staying away from their spouse for longer periods and males being promiscuous by habit put them being at greater risk for HIV infection. Moreover, the male preponderance might have been due to the fact that in the existing social scenario in India females do not seek medical care fearing ostracism and loss of family support. Our results are consistent with a study from Surat, India in which $64.4 \%$ participants were males [10].

Majority of the subjects in our study were from urban areas (69.4\%), which is in contrast with a study conducted in South India where $67 \%$ subjects were from rural areas [11]. This observation

Table 2: Clinical status of all study subjects $(n=252)$.

\begin{tabular}{|l|l|l|l|}
\hline Characteristic & & No. & $\%$ \\
\hline \multirow{3}{*}{ WHO clinical stage } & Stage I & 125 & 49.6 \\
& Stage II & 42 & 16.7 \\
& Stage III & 79 & 31.3 \\
& Stage IV & 6 & 2.4 \\
\hline \multirow{3}{*}{ Functional* status } & Working & 215 & 85.3 \\
& Ambulatory & 32 & 12.7 \\
\hline
\end{tabular}

${ }^{*}$ Functional status: Working- Able to perform usual working or out of the house harvest etc

Ambulatory- Able to perform activities of daily living but not able to work

Bedridden- Not able to perform activities of daily living

Table 3: CD4+ T lymphocyte counts of study subjects $(n=252)$.

\begin{tabular}{|c|c|c|}
\hline WHO Clinical Stage & $\begin{array}{c}\text { CD4+ T lymphocyte count } \\
\text { Median (Cells/pl) }\end{array}$ & $\begin{array}{c}\text { CD4+ T lymphocyte count } \\
\text { (IQR) }\end{array}$ \\
\hline Stage I $(N=125)$ & 511 & $380-615$ \\
\hline Stage II $(N=42)$ & 284 & $167-421$ \\
\hline Stage III (N = 79) & 191 & $103-383$ \\
\hline Stage IV $(N=6)$ & 36 & $33-41$ \\
\hline Total $(\mathrm{N}=252)$ & 279 & $154-482$ \\
\hline
\end{tabular}

could again be due to the fact that Delhi being the capital city of India has the maximum number of migrant population from all over the country.

Majority (79.6\% males and $61.1 \%$ females) of the study patients were married in our study. $44.9 \%$ of males had HIV positive partners while $82.3 \%$ females had HIV positive partners. This again shows a male predominance of HIV infection. This finding was more or less similar to the study conducted by Bhandarkar et al in Karimanagar wherein the spouse positivity was higher among females i.e. $49.8 \%$ as compared to males i.e. $32.9 \%$ [12].

A significant proportion (27.7\%) of our study patients were illiterate ( $26.9 \%$ males and $29.4 \%$ females) and only $20.2 \%$ of patients had received education above intermediate level. This suggests that higher educational levels offer some protection against HIV. Anybody who is illiterate and educated below the secondary education level may not have adequate knowledge for protecting himself or herself from sexually transmitted diseases, including HIV/AIDS. This was in accordance with the findings of the study which was conducted by Chennaveerappa PK et al, where $32 \%$ of the male seropositive subjects and $45 \%$ of the female seropositive subjects were illiterates [11].

Maximum numbers (45.2\%) of subjects were employed in unskilled and semiskilled occupations. $47 \%$ females were housewives while only $3.5 \%$ males were unemployed. Our observations are similar to a study by Gupta in Udupi where the most common source of income for males (48.8\%) was semi-skilled occupation, such as bidi rolling and fishing. Among females, 30 (34.2\%) were housewives and $23(26.1 \%)$ were working as housemaids or laborers [13]. Most of the subjects belonged to the lower social class ( $70 \%$ of the males and $69.2 \%$ females) according to modified Kuppuswamy's scale and had a median per capita income of Rs 1000/- per month. Our findings corroborate with that of another study in Delhi where majority (91.5\%) of them were from low socio-economic status, with more than $90 \%$ drawing monthly income $<$ Rs 5000/- [14]. Socioeconomic class which was determined on the basis of education, occupation and per capita income are modifiable. Here we see a window of opportunity, if specific measures were applied can help in improving the socioeconomic class of a population, leading to a decrease in HIV transmission.

In our study the commonest mode (72.2\%) of acquiring infection was through heterosexual contact. Route of transmission could not be identified in $15.5 \%$ cases. This finding is somewhat similar to what was reported by Sharma from Ahemdabad where sexual route accounted for infection in $63 \%$ cases while in $22 \%$ cases mode of transmission could not be elicited [9].

$66.3 \%$ of our cases were in WHO clinical stage I \& II of illness at the time of registration in the ART clinic. This is in accordance with what was seen in a study in Surat where more than two third patients were in their first and second stage of disease at the time of registration [10].

The median CD4+ T lymphocyte count for all patients was 279 Cells $/ \mu$ l. The CD4+ count showed an inverse relationship with the clinical stage of the disease, counts being lower in cases with clinical stage III \& IV. Bhandarkar et al reported similar results with a mean 
CD4+ count among ICTC patients being 270.63 cells [12].

Although, in our study, we have tried to correlate the HIV seropositive status of the individual with the several sociodemographic factors, but their presence is merely an observation. There is a need to conduct further studies which could establish the direct correlation between these socio-demographic factors \& HIV seropositivity status.

\section{Conclusions}

A significant number of our subjects were in the economically productive age group and majority of patients were males indicating that this disease is causing a great loss to the nation's booming economy. The other socio-demographic determinants found to be associated with HIV positivity were literacy status, occupation, socioeconomic status and place of residence. Since higher literacy helps in getting a better job and increased per capita income, which leads to improvement in the socio-economic status of the individual, so just by working on improvement of literacy status we will be able to modify the other socio-demographic determinants; authorities need to focus on this. Also, increased literacy will help in better understanding about the disease, its mode of transmission, personal protective measures to be employed and societal responsibilities at the individual level, which will help to a great extent in preventing the spread of this pandemic.

The commonest mode of acquiring infection was heterosexual contact, emphasizing the need to strengthen our Information education \& communication (IEC) strategies to contain HIV/AIDS. $66.3 \%$ of our cases were in WHO clinical stage I \& II at the time of registration in the ART clinic. This is a positive sign as this reflects heightened awareness among those affected and highlights the good counseling services of our ICTC centers.

\section{Acknowledgements}

We highly appreciate the technical assistance provided by the technical staff of HIV laboratory of Maulana Azad Medical College, New Delhi, India. We would also like to thank the staff of ART clinic of Lok Nayak Hospital, New Delhi, India.

\section{References}

1. Kallings LO (2008) The first postmodern pandemic: 25 years of HIVIAIDS (Review). J Intern Med 263: 218-243.

2. Piot P, Bartos M, Ghys PD, Walker N, Schwartlände B (2001) The global impact of HIVIAIDS. Nature 410: 968-973.

3. UNAIDS (2010) Report on the global AIDS epidemic. [Internet].

4. Steinbrook R (2007) HIV in India - A Complex Epidemic. N Engl J Med 356: 1089-1093.

5. Chandrasekaran P, Dallabetta G, Loo V, Rao S, Gayle H, et al. (2006) Containing HIVIAIDS in India: the unfinished agenda. Lancet Infect Dis 6: 508-521.

6. Mawar N, Sahay S, Pandit A, Mahajan U (2005) The third phase of HIV pandemic: Social consequences of HIVIAIDS stigma \& discrimination \& future needs. Indian J Med Res 122: 471-484.

7. Department of AIDS Control, National AIDS Control Organization, Ministry of Health \& Family Welfare, Government of India, Annual Report 2010-11. [Internet]. 2011 [cited 2011 Sept17].

8. Park K, Bhanot B (2009) Kupuswamy Park's textbook of preventive and social medicine. Jabalpur: Banarsidas Bhanot Publishers.

9. Sharma R (2011) Profile of HIV-positives and determinants with mode of transmission of HIVIAIDS patients on anti-retroviral treatment center at civil hospital, Ahmedabad. Indian J Sex Transm Dis 32: 14-18.

10. Sonani HP, Undhad AM, Savani GT (2011) Clinical and socio-demographic profile of patients registered at ART centre, SMIMER, Surat. National Journal of Community Medicine 21: 130-132.

11. Chennaveerappa PK, Halesha BR, Vittal BG, Jayashree N (2011) A study on the socio-demographic profile of the attendees at the integrated counselling and testing centre of a medical college in south India. Journal of Clinical and Diagnostic Research 5: 430-433.

12. Bhandarkar PN, Mohd S, Kannan K, Jogdand GS (2011) Socio-demographic Profile of HIV patients at ICTC, CAIMS, Karimnagar. Int J Biol Med Res 2: 1023-1025.

13. Gupta M (2009) Profile of Clients Tested HIV Positive in a Voluntary Counseling and Testing Center of a District Hospital, Udupi. Indian J Community Med 34: 223-226.

14. Khan MA, Sehgal A (2010) Clinico-epidemiological and socio-behavioral study of people living with HIVIAIDS. Indian journal of psychological medicine 32: $22-28$. 